Historic, Archive Document

Do not assume content reflects current scientific knowledge, policies, or practices. 


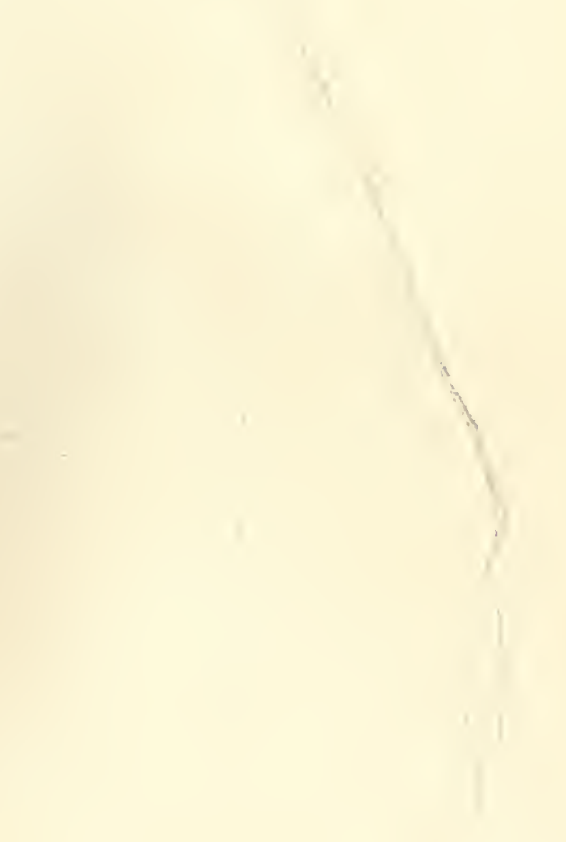


48 $\mathrm{THE}-3$.

\section{JOE L. ULLATHORNE SEED CO. Garden, Field and Flower Seed}

Operating

Morning View Seed Farms Attala County, Miss.

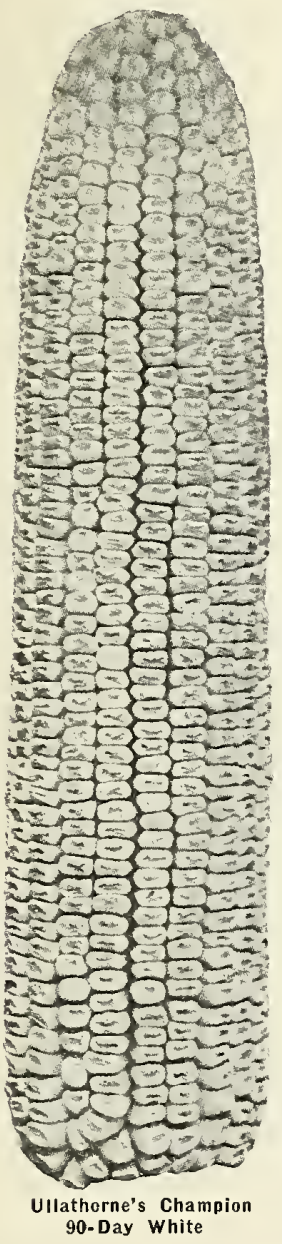

MEMPHIS, TENN.

SELECTED SOUTHERN GROWN SEED CORN OUR SPECIALTY

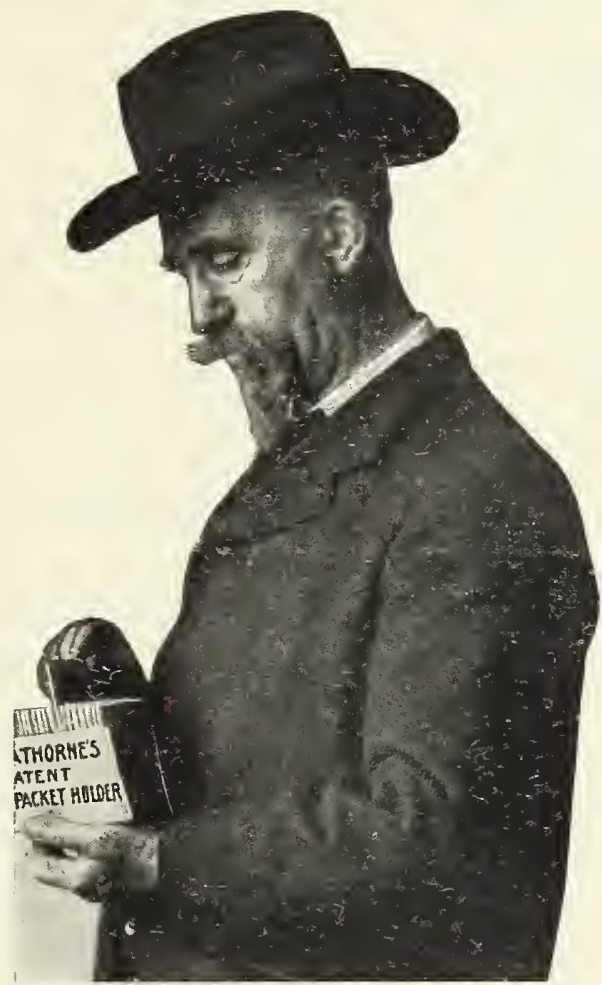

JOE L. ULLATHORNE, Pres.

Identified with the seed business in the South since 1870 .
Operating

Harpeth Valley Seed Farms Williamson County, Tenn.

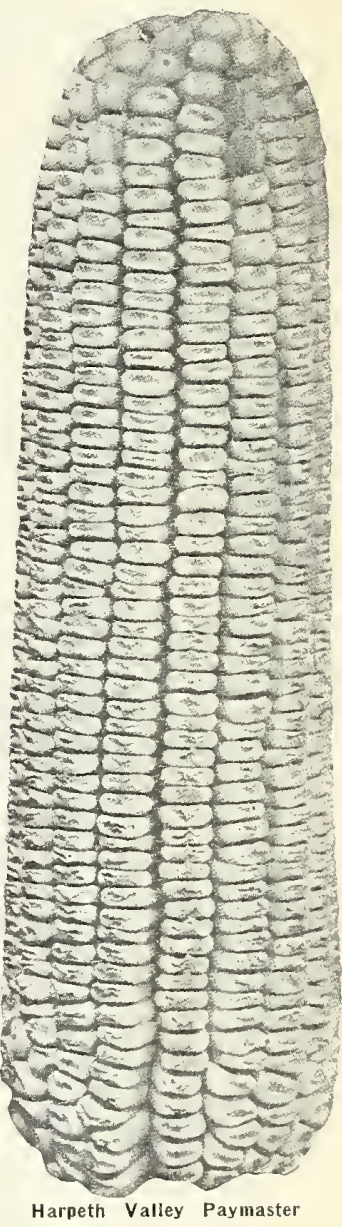

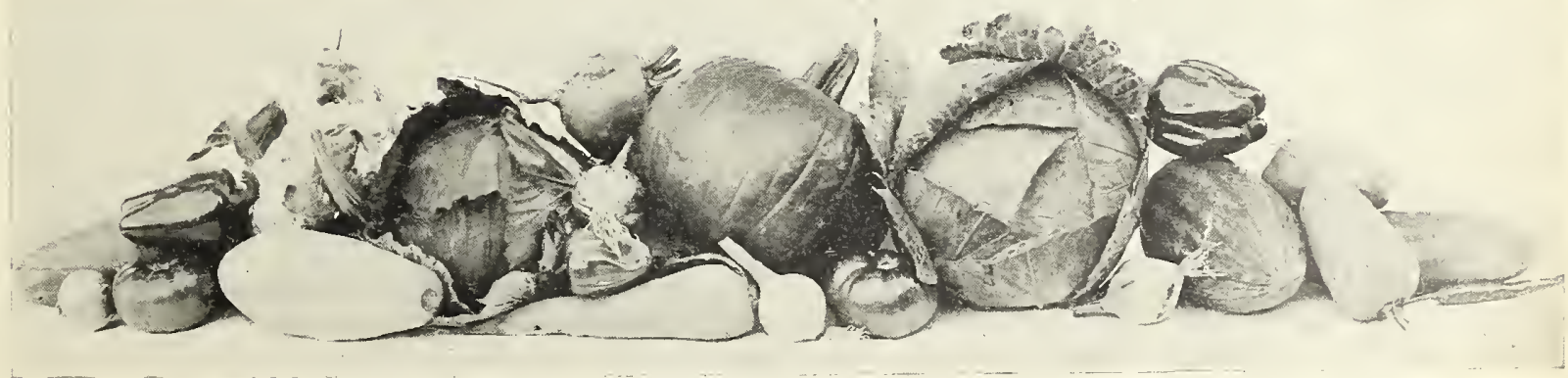




\section{A Personal Letter from Our President.}

\section{TO MY FRIENDS AND GUSTOMERS}

\section{GREETINGS:}

For over fifty years I have been identified with the Seed Business in the South. For over fifty years I have been selling absolutely the best seeds that could be obtained. I have introduced many varieties of vegetables to the South that are now as staple as sugar and coffee. I am proud of the reputation which Ullathorne's seeds enjoy.

Realizing the truthfulness of the motto, "He profits most who serves best," I have ever had my customer's interest at heart. I have never mis-represented anything in order to make a sale and never shall I do so. That is why the name Ullathorne bears such significance, when connected with seed, whether a five-cent package or a carload. That is why I have been able to sell seed in the same families for three generations.

While I am out on our fields, the Harpeth Valley Seed Farms, where I give my personal attention to the breeding, growing, harvesting and selecting many of the seeds we sell, I feel that my customers are being well cared for by Mr. J. L. Mitchell, our Secretary-Treasurer and Store Manager.

Mr. Mitchell is a Mississippi farm raised boy, who was educated at the Mississippi A. \& M. College, and has had twelve years practical experience. His education and experience has gained for him a vast knowledge of farm questions and makes him a competent man to go to for advice.

I have known him personally for a number of years. I liked his fair way of dealing with his customers, and at the first opportunity, I got him to come with us. I want you to feel and to know that when you send your orders to him, you will get a fair, square deal every time.

I do thank you for your liberal patronage, and wish you every success.

Sincerely yours,

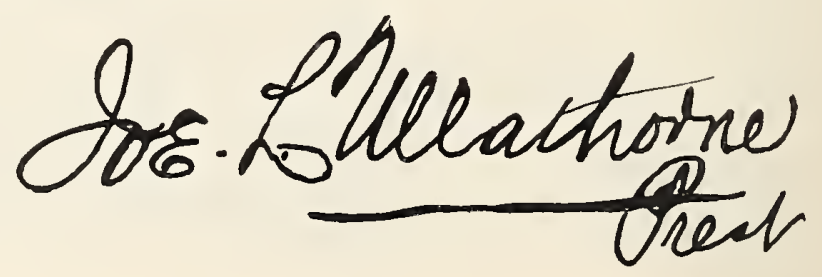




\section{Ullathorne's Selected Southern Grown Seed Corn and Why You Should Plant it.}

During the last twelve years in which I have been identified with the seed industry of the South, it has been my good fortune to visit a great many corn shows, district, county, state and national exhibitions. I have paid a great deal of attention to the corn question in the South. I know a great number of the breeders and dealers personally, but I do not know of a man who has spent as many years or as much money for the betterment of the corn industry of the South as has our Mr. Joe L. Ullathorne. In fact, Mr. Ullathorne has been so closely identified with seed corn for the last forty years that he is familiarly known as "The Seed Corn Man."

Mr. Ullathorne discovered early in his work that the heaviest yields of corn could not be produced in the South if Northern or Western seed corn was used, regardless of how excellent it might have been in its native heath. Did you ever hear of a Southern Corn Club boy winning the prize by planting Northern grown seed corn? Did you ever hear of Northern grown seed corn leading at any of the Southern Experiment Stations? No! And you never will.

There are a great many farmers who would not think of raising cattle from a scrub bull, nor try to raise draft horses from running stock; yet, these self-same farmers will go to their cribs or their tenant's cribs and get their "seed" corn and expect to make a bumper crop. If this corn is planted in rich soil and has a good season it may make a good crop and greatly please the planter; yet, if he had a test field of Ullathorne's pure-bred corn to show the difference in yield he would see that his scrub seed corn cost him about $\$ 15.00$ per bushel.

Practically the same thing happens when a farmer plants Northern grown seed for "early feed." If he would keep records of these "early feed" patches he would find that he could better afford to pay two prices for the feed to use until his Ullathorne Corn matured. If Ullathorne's Seed Corn is planted exclusively there will be no need for "early feed." If you could see the care that is used in growing, selecting and preparing Ullathorne's Seed Corn and compare it with the so-called seed corn which is offered freely with wonderful stories of its breeding, etc., you would never plant anything but Ullathorne's Seed Corn.

LOOK OUT FOR CHEAP SEED CORN THIS SEASON. Owing to the favorable season for corn growing last year, a great many made more corn than usual and think that they have real seed corn, when, as a matter of fact, their corn is no more seed corn than it ever was. What you want is REAL SEED CORN that will make the most corn, poor season or good season. ULLATHORNE'S SEED CORN is just this kind of Seed Corn.

For over thirty years, Mr. Ullathorne has been breeding his corn for greater perfection. He has his fields carefully roughed and every barren stalk is taken out before it has time to scatter its pollen to the stalks from which seed is to be saved. At the same time, he cuts down all weak stalks and stalks that show any signs of disease. After all this is done, none but the best ears go into our seed corn. Don't you know that this work is expensive? Don't you know that a bushel of this kind of corn is worth far more than two bushels of ordinary crib-selected, so-called seed corn is worth to you? Can you afford to take chances on losing a corn crop for the sake of saving (?) a few cents an acre on the price of seed?

\section{HARPETH VALLEY PAYMASTER CORN}

(See illustration on front page)

Harpeth Valley Paymaster-The $\mathbf{1 0 0}$ per cent Two-Ear Corn-will outyield any other corn in the world! We breed it up to produce heavier yields of small red cob, deep grain corn, than any other variety in existence. This is an absolutely 100 per cent two-ear corn, many stalks with three and four ears. We have gone through our fields time and again looking for stalks with less than two ears, and we have yet to find one.

A deep, white grain, on a small bright red cob, stands the drought, has a short, stocky stalk, does not blow down easily, and will mature anywhere in the South, as it is strictly a 100-day variety. Big Yielder-75 to 125 bushels per acre-according to soil. Read what our customers who planted this corn say about it; also get your Experiment Station records. Don't be content to plant just "Paymaster Corn." Insist on Harpeth Valley Paymaster. Because he knows how well Mr. Ullathorne breeds and selects his seed corn, one of our best customers wants 500 bushels of our own Harpeth Valley Paymaster this season, although he already has over ten thousand bushels of his own growing. Our selected seed corn costs more per bushel, but it is economy to plant it. Peck, $\$ .85 ; 1$ Bushel, $\$ 2.90 ; 21 / 2-B u$. Sack, $\$ 6.75 ;$ F.O.B. Memphis. 


\section{ULLATHORNE'S CHAMPION 90-DAY WHITE}

The ideal corn for the South is an early variety, that will produce a big yield before the drought sets in. Ullathorne's Champion 90-Day White is such a corn. It is the Earliest Large White Corn in the World! It is an Early White Dent, coming in almost as early as the Adams Early, but much larger; sample ears have been shown us 14 inches in length and $31 / 2$ inches in diameter. For stock feeding it is very valuable, coming in as it does when all fodder is short, it fills a breech which all stock feeders can appreciate. Again, it is a coln which has made itself before the hot dry weather, when all field varieties must make their growth.

TWO CROPS OF CORN A YEAR can be made on the same ground, making it doubly profitable to grow. The constantly increasing demand for this corn is sufficient proof for all we claim for it.

Although a planter may have plenty of coln in his crib, it pays to buy his Seed Corn every year. Every planter knows how quickly a type of corn runs out. Fifteen days often proves to be a critical time of ear formation and maturity, and the whole crop is either ruined or made, just as you plant your own corn of our Early Thoroughbred Seed Corn. Many planters say if they had not planted our Champion 90-Day White Corn last year they would not have had any corn, as their own grown corn crop was an entire failure.

Description-The illustration on first page is a true picture, from a photograph of this corn, showing its general type and character. Every stalk produces from one to two good ears, and this is where its large, heavy yields come in. The stalks are large, robust, growing to a height of 8 to 12 feet, dependent upon land; has a very heavy and extensive root system and this is where its vitality to resist drouth and hot weather comes in. Ears run from 10 to 13 inches long, but usually 10 inches, 16 to 20 rows, deep kernels with large, full germs, firmly set in a pure white cob of medium size. In short, we breed this coln with a single eye to heavy yields and early maturity and not for show purposes. Send for sample grains. Price: Peck, 85c; 1 Bushel, $\$ 2.90 ; 21 / 2$ Bushel Bag, $\$ 6.75$. F. O. B. Memphis.

\section{ULLATHORNE'S GIAN'T TENNESSEE RED COB WHITE}

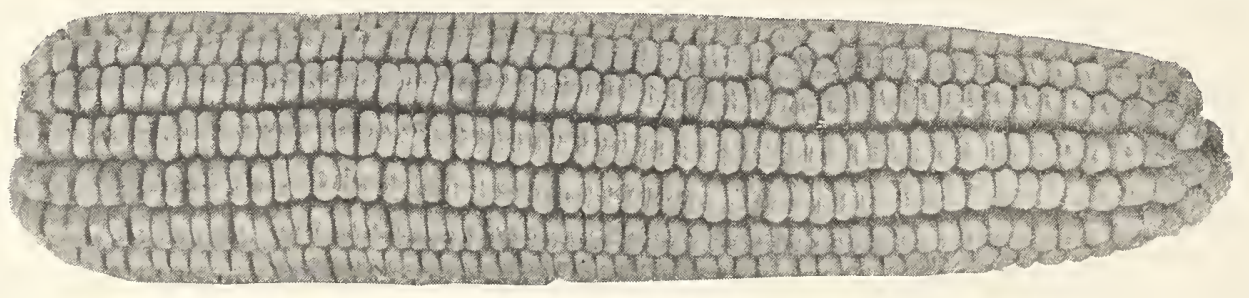

Without a doutt, this is the largest yielding and one of the highest feeding and best milling corns in the world. For ensilage it cannot be surpassed. The stalks are 8 to 12 feet high, broad and short jointed, foliage broad leaved and full. Ears 9 to 13 inches long, 16 to 22 rows, with a deep, broad grain, pure white on a red cob of medium size, averaging one large and one small ear to the stalk. The judges at the 1917 Tri-State Fair would not permit our Giant Tennessee Red Cob Corn to enter competition, as they stated the ears were so large that they were "out of proportion." It is the most ideal corn we have ever seen grown in any corn growing section. Price: Peck, 85c; 1 Bushel, $\$ 2.90 ; 21 / 2$ Bushel Sack, $\$ 6.75$.

\section{ULLATHORNE'S MASTADON TENNESSEE RED CORN}

Won Championship of entire Corn Show at Memphis and Nashville, Tennessee, Fall, 1919, in competition with the entire South.

Mastadon Tennessee Red is an early maturing corn and a great favorite wherever known. It is superior for Feeding and Silage, stock feeders claiming one bushel is equal to $11 / 4$ bushels of ordinary corn. This corn is by no means as handsome as some of our other varieties, but it is iron-clad and of intense vitality to resist unfavorable conditions-cool nights, extreme wet or dry weather and can always be relied upon to make a crop when others fail.

Mastadon Tennessee Red Corn is a very large variety of unusual size and length. On good land the ears will run from 11 to 13 inches, with occasional specimens 14 inches long. Grain $5 / 8$ inch long and very wide and thick. Fourteen to sixteen rows. This is another triumph of Mr. Ullathorne's skill as a corn grower and breeder, as shown by the following from Mr. E. P. Mangum, Tunica, Miss.: "My crop of Ullathorne's Mastadon Tennessee Red Cob Corn was a wonder to my neighbors. I sent four ears to the Merchants Exchange, Memphis, that weighed seven pounds." Send for sample grains. Price: Peck, 85c; 1 Bushel, $\$ 2.90 ; 21 \% 2$ Bushel Sack, $\$ 6.75$. 


\section{HICKORY KING CORN}

A very popular and productive white corn, especially for high land, and it is in great favor with those who have planted it. It produces on good soil three or four average sized ear's to the stalk. The grain is large, broad and beautifully white, making the finest quality meal. The cob is often so small that a large-sized grain will cover the end of it. Price: Peck, 85c; 1 Bushel, $\$ 2.90 ; 21 \% 2$ Bushel Sack, $\$ 6.75$.

\section{REID'S EARLY YELLOW DENT}

This is one of the earliest varieties of Yellow Dent Corn grown in Tennessee. It has a number of years of Mr. Ullathorne's breeding and selecting behind it. Because it has become acclimated it produces much ketter than Northern grown seed. The ear is almost ideal, from eight to ten inches long and from 12 to 16 rows of deep yellow grains on a dark red cob. Matures in about 110 days. Don't confuse our Tennessee grown selected seed with the chcap Northern stocks. Price: Peck, 85c; 1 Bushel, $\$ 2.90 ; 21 / 2$ Bushel Sack, $\$ 6.75$.

\section{ULLATHORNE'S SILVER MINE}

The original of this variety was secured from one of the best fields of corn Iowa ever produced. Mr. Ullathorne has been growing and selecting his seed on his Williamson County, Tennessee, farm, for a number of years and has not only gotten the variety acclimated, but has increased the yield and the uniformity of the ears. While probably a few days later in maturing than corn direct from Iowa, the increased yield is well worth waiting for. Price: Peck, 85c; 1 Bushel, $\$ 2.90 ; 21 / 4-\mathrm{Bu}$. Sack, $\$ 6.75$.

\section{EXTRA SELECT MOSBY PROLIFIC CORN}

We are breeding our stock of Mosby to grow not over ten feet high, to grow with a heavy stalk as thick as your wrist at the ground and tapering to a whip-like top. Two to three ears to a stalk is our aim. We don't care to produce more than this number, as we want to get the growth out of the long stalk and into the ears. Ears of our Mosby are from one to two inches longer than ordinary stock, with very small cob, and deep, pearly white grain. This is just the ideal Prolific Corn for those who care for this variety; it will not rot under the influence of too mucl moisture and will stand a good deal of drouth. Matures in about 130 days. Send for sample grains. Price: Peck, 85c; 1 Bushel, $\$ 2.90 ; 21 / 2-B u$. Sack, $\$ 6.75$.

\section{ULLATHORNE'S MAMOTH WHITE JUNE CORN}

Our strain of June Corn is vastly superior to the Mexican June, as we consider this variety a mongrel of the worst type. The Mammoth White June Corn is a beautiful snowflake white, soft and of fine texture. Ears average eight to ten inches, always filled out from tip to butt and very uniform in size and type. It has a decided double ear characteristic, one reason for its fine yield records. Within the past four or five years this famous June Corn has become better known by its introduction thruout the South.

Mr. J. H. Kibler, of Rome, Miss., planted this corn late last June and now tells us if it were not for this corn he would not have an ear to feed on.

Get away from planting Mexican June, as Ullathorne's Manmoth White June Corn will produce a much heavier crop of better corn than any June variety in existence. Send for sample grains. Price: Peck, 85c; 1 Bushel, $\$ 2.90 ; 21 / 2$ Bushel Sack, $\$ 6.75$.

\section{ULLATHORNE'S GOLDEN YELLOW DENT CORN}

Developed by our Mr. Ullathorne at the same time he was developing our famous Champion 90Day White Corn. Large Golden Yellow Dent is an early 90-day corn and matures considerably in advance of the ordinary Southern varieties. A beautiful Rich Golden Color; large deep grains with large, oily germs; medium cob, 16 to 22 rows, many ears weighing a pound and a half each. While not a two-ear variety, many of our customers class it as such. We have yet to find a field of this variety with over 5 per cent barren stalks. The stock and chicken feed manufacturers always pay a premium for this rich colored corn. After our stocks are sold, we will have no more to offer, as we do not buy a grain of corn from other growers. Send for sample grains. Price: Peck, 85c; 1 Bushel, $\$ 2.90 ; 21 / \underline{\text { Bushel }}$ Sack, $\$ 6.75$. 


\section{COTTON SEED}

While we make no attempt to prophesy the reduction or increase in the cotton acreage for 1922, we know that there will be a good many million acres planted. We also know, that with the same care and attention, this acreage will produce a great deal more cotton if planted with real,selected, pedigreed, trueto-name cotton seed than it will if planted with gin-run seed, but we have no seed to offer you that will make a crop without work.

We are listing only those varieties that have proven themselves worthy of being planted, and we liave absolutely the best selections of the best strains of these to offer to our customers. Our seed may cost a little more in the beginning to plant them, but it will cost you more in the end if you do not plant them.

MITCHELL'S RE-IMPROVED EARLY KING. This is a short staple, small boll variety of cotton that has been bred for its heavy yielding and quick maturing qualities. It is well adopted to both hill and bottom lands and is without exceptions the earliest variety that can be planted. Bu. (32-lbs.), $\$ 2.25 ; 100-1 b s$., $\$ 6.50$; 300-lbs., $\$ 17.50$, all F.O.B. Memphis.

WANNAMAKER IMPROVED PEDIGREED CLEVELAND BIG BOLL. This is earliest of the big boll varieties of cotton, coming in only a few days later than the King and Simpkin small boll types. It is a heavy yielding, high-linting, storm-proof variety that is well-known and highly regarded throughout the entire South-Short staple. Bu. (32-lbs.), $\$ 2.50 ; 100$-lbs., $\$ 6.75 ; 300-1 b s ., \$ 18.00$.

MEBANE TRIUMPH. This is an early variety of Bender cotton that was originated in Texas some fifteen years ago and where it is more largely grown than any two other varieties. It is a big boll, stormproof variety, that produces a heavy yield of seed cotton and gives about $40 \%$ turn-out at the gin. 'The fibre is very strong and it brings a premium over the short staples. Bu. (32-lbs.), $\$ 2.50 ; 100-1 b s ., \$ 6.75$; $300-l b s ., \$ 18.00$.

EXPRESS-350. A most desirable variety for rich bottom lands. This is a selection from the original Express, which is much earlier and which gives a much higher per cent of lint than the parent variety. It has a medium size boll, usually five locks, which makes it easier to pick. To sum it up in a few words, we will say that Express-350 is the heaviest yielding, quickest maturing, highest linting long staple variety of cotton known. Our seed was grown in Northern Arkansas and is the best to be had. Bu. (32-lbs.), $\$ 2.50 ; 100$-lbs., $\$ 6.75 ; 300-l b s ., \$ 18.00$.

\section{TESTIMONIALS}

We appreciate the $\$ 10.00$ prize which you gave to the Club boys of this County. We made some wonderful productions from your Harpeth Valley Paymaster Seed Corn, some of them being listed below: Floyd Broadfoot, 108 $\frac{1}{2}$; Ray Paulk, 72; Andrew Thrasher, 87; Fred Paulk, 64; Bradford Paulk, 66 bushels per acre. The productions were properly witnessed by good men who were disinterested parties. J. T. High, County Agent, Florence, Lauderdale County, Alabama. October 25, 1921.

Gentlemen: Was more than pleased with the seed corn I got of your firm this spring. Your Paymaster certainly made me a good crop. I think anyone would be pleased with it or any other of your seed corn. I was told several times that I had as good corn as was grown in the regular corn belt.
Respectfully,
R. E. ROSE.

Gentlemen: I am pleased with your seed corn. Think you have the best in the country. J. J. LONG.

Gentlemen: Replying to yours of 7 th, beg to say the seed corn purchased of you proved satisfactory in every respect and I shall want another supply for spring planting.
Yours truly,
H. R. PARK.

Gentlemen: Owing to the extreme wet spring and hail storm and the shortage of labor, your corn did not have a fair test. But I like it better than any I have ever planted and will make a fairly good crop. Respectfully,

W. R. IRBY.

Gentlemen: The seed corn I bought of you (Paymaster) was planted July 2nd and was in eating condition about first week in September. I think it will turn out forty bushels per acre and will do to crib about 1 st to 10 th of November. Expect to want more another year. 


\section{VEGETABLE SEEDS}

During our half century's experience in growing and selling seeds to Southern planters, we have gained knowledge that is of great value, not only to us, but to our customers as well. We know where each variety grows best and who grows them; we know just what variety should be planted in each section of our vast trade territory. You get the benefit of this knowledge without extra charge, when you plant Ullathorne's seeds, whether you buy them direct from us or from one of ULLATHORNE'S LIT'ILE SEED STORES, which you will probably find at your nearest grocery, put there for the convenience of those who plant only small quantities, but who want the best.

We believe that practically all our customers are familiar with the standard varieties of vegetables grown in the South and that descriptions from us are unnecessary. We have arranged our list in alphabetical order, which will be found quite a convenience in making out your order.

A lot of colored pictures, together with extravagant statements from us, might sell a few more seeds, but they would not make your vegetables a bit better, for we handle but one grade and that one is absolutely the best that can be had, regardless of price. Don't be misled by fancy, new names and high prices, for old varieties. Order what you need from this list and you will be more than satisfied.

\section{ARTICHOKE} $\begin{array}{cccc}\text { Pkt. } & \mathrm{Oz} . & 1 / 4-\mathrm{Hb} . & \text { tb. } \\ \$ .10 & \$ .60 & \$ 1.60 & \$\end{array}$

Green Globe Freneh

ASPARAGUS

Columbia Mammoth ....................... .05

Barrs Mammoth

Palmetto

\section{BRUSSELS SPROUTS}

Perfection n

Eelipse

\section{BEETS}

Crosby Egyptian

Early Blood Turnip

Early Bassano

Market Gardener's

Detroit Dark Red.

White French Sugar

ar

Long Red Mangel

BUSH BEANS-Green Pod

Early Red Valentine

Burpees Stringless

Giant Stringless

Black Valentine

Tennessee Green

\section{BUSH BEAN-Wax Pod.}

Improved Gol Wax

\section{BEANS-POLE-Snap}

Kentueky Wonder

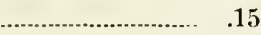

St. Louis Perfection

Seotia-Striped Cornfield

White Creasbaek

\section{BEANS-BUNCH, Lima}

Hendersons Bush Lima................... .15

Burpees Bush Lima

BEANS-POLE, Limas

Carolina Sieva (small)

King of Garden (large)

CABBAGE

Charleston Wakefield

Jersey Wakefield

Early Winningstadt

Copenhagen Market

Early Summer ...

Drumhead Savoy

Flat Duteh

Drumbead

Sueeession

Eureka

.05

.10
10
.10

.10

$\$ .10$

$\$ .25$

$\$ .75$

\section{.05}

.10

Pkt. 1/2-Pt.

\section{.15} .15

\section{POSTPAID}

$\$$

.80
.80
.80
2.00
.75

60

.20

Pt.

.35

.35

.35

.35

.35

Qt.

.60

.65
.60

.65

.65

.20

.35

.35
.35

.60

.60

.35

.35

.35

.35

.65

.65

.65

.35

.40

.65

.75

.35

.65

$\begin{array}{ll}.40 & .75\end{array}$

$1 / 4-1 \mathrm{~b}$.

Plit.

.05

.05

.05

.05

.05

.05

.05

.05

.05

.05

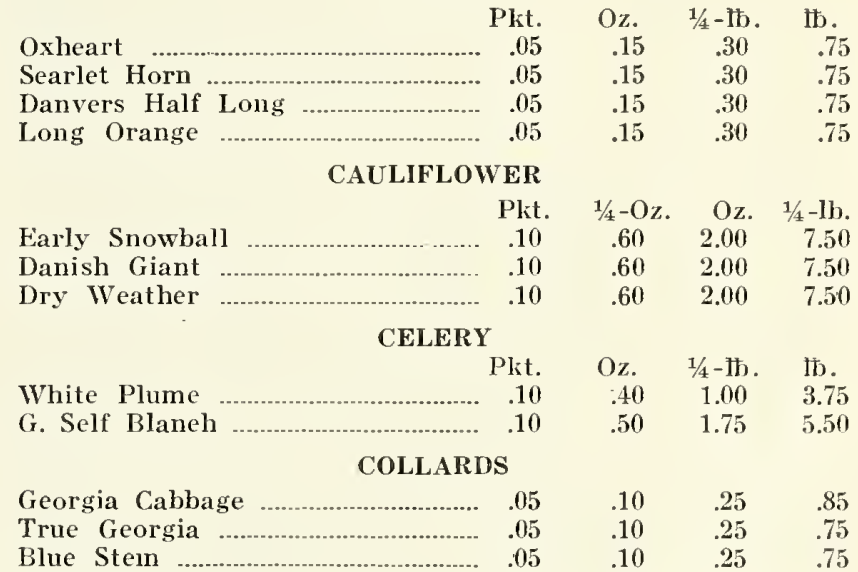

CHICORY

Large Rooted .10

CORN-Garden

$$
\text { Plit. }
$$

Blaek Beauty .................................. 05

ENDIVE

Green Curled KALE OR BORECOLE

Dwarf Green Curled

$\begin{array}{rr}\text { Plit. } & \text { Oz. } \\ .05 & .15 \\ .05 & .15\end{array}$

Tall Green Scoteh
Extra Early Adams

Large Adams

Stowels Evergreen

Country Gentleman

Golden Bantam

Surprise

Ch. White Dent

Pt.
.25

.25
.25

.30

.30

30

.30

CUCUMBER

Early White Spine..

Plit.

Davis Perfeet

lmproved Long Green

Chicago Piekling

Early Cluster

Gherkin or Burr

KOHL RABI

White Vienna LEEK

Large London or Flag................ 05

Gal. $.40 \quad 1.00$ 
Big Boston

Oz. 1/4-1b. Ib.

Cal. Crcam Butter

N. Y. Wonderful

Prizehead

Mignonette

Simpsons Ey. Curled

$\begin{array}{lll}.20 & .40 & 1.25 \\ .20 & .40 & 1.25 \\ .25 & .75 & 2.50 \\ .20 & .60 & 1.65 \\ .30 & .75 & 2.75 \\ .20 & .50 & 1.25\end{array}$

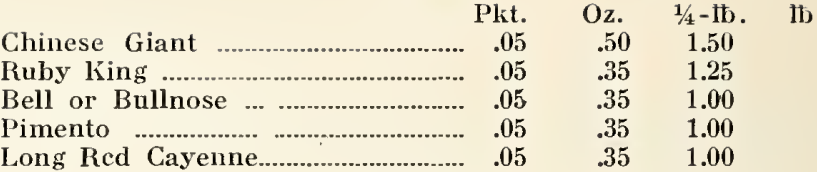

\section{MUSK MELON}

Pollock Select 10-25 ...........

Rockyford Ex. Select............................

Burrell's Gem .................................... .0

Banana or Quill ..................................

Baltimore or Acme ............................ .05

Honey Dew ..................... 05

Golden Netted Gem ............................. .05

\section{WATERMELON}

Tom Watson Ex. Select.................. .05

Sweetheart ...........................-............. $\quad .05$

Alabama Sweet ................................

Black Diamond ................................... .05

Florida Favorite .............................. .05

Georgia Rattlesnake ........................ $\quad .05$

Irish Grey .05

Halbert Honey ...................................... .05

Kleckley Sweet

\section{MUSTARD}

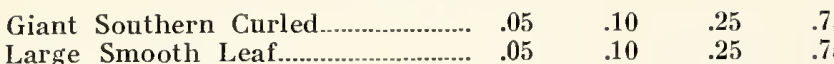

OKRA

White Velvet

Long Green ............................................... .05

Dwarf Green

White Globe .05

White Silver Skin ......................... .05

Yellow Globe Danver ...................... .05

Red Weathersfield …........................ .05

Southport Red Globe

$\begin{array}{lll}.20 & .50 & 1.50 \\ .20 & .50 & 1.50 \\ .20 & .50 & 1.50 \\ .20 & .50 & 1.50 \\ .20 & .40 & 1.25 \\ .25 & .65 & 2.00 \\ .20 & .35 & 1.25\end{array}$

PUMPKIN

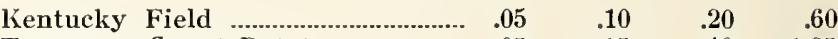

Tonnessee Sweet Potato .................

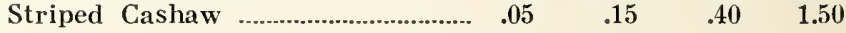

RADISH

Ey. Scarlet Turnip

Ey. Scarlet Turnip W. T................ .05

French Breakfast .............................. .05

Long Scarlet Short Top ................... .05

Crimson Giant

Ullathorne Fancy Mixed …............. .05

White lcycle

Chinese Rose Winter ....................... . .05

Long Black Spanish .............................

Round Black Spanish ....................... .05

SPINACH

Bloomsdale Savoy …........................ .05

Long Standing ...................................... $\quad .05$

New Zealand

SQUASH

\begin{tabular}{|c|c|c|c|c|}
\hline \multirow{2}{*}{\multicolumn{5}{|c|}{ Ey. White Bush }} \\
\hline & & 15 & 35 & \\
\hline Mammoth White Bush ................. & .05 & .15 & .35 & 1.25 \\
\hline Summer Crookneck ............................. & .05 & 15 & .35 & 1.25 \\
\hline Hubbard .................................................. & .05 & 20 & .50 & 150 \\
\hline \multicolumn{5}{|l|}{ SALSIFY } \\
\hline Mammoth Sandwich lsland ............. & .05 & .15 & .50 & 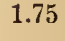 \\
\hline TOMATO & & & & \\
\hline 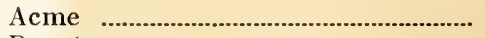 & .05 & .30 & .85 & 2.7 \\
\hline Beauty & .05 & .30 & .75 & 2.1 \\
\hline Livingston Globe & .05 & .35 & 1.00 & \\
\hline Earliana & .05 & .35 & .85 & 3.0 \\
\hline 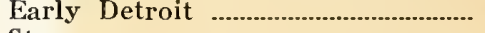 & .05 & .35 & 1.00 & 3.5 \\
\hline Stone & .05 & .30 & .75 & \\
\hline Ponderosa & .05 & .40 & 1.25 & \\
\hline Dwarf Champion (Tree)................... & .05 & .35 & .85 & 2.7 \\
\hline Yellow Pear ..................................... & .10 & .50 & 1.50 & \\
\hline
\end{tabular}

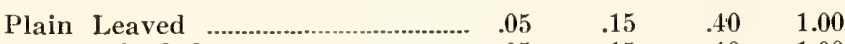

Double Curled ….......................................

PARSNIP

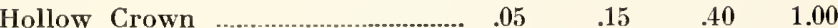

GARDEN PEAS

Pkt. 1/2-Pt. Pt. Ot. Gal

\begin{tabular}{|c|c|c|c|c|}
\hline Alaska & $\begin{array}{c}\text { Pkt. } \\
.15\end{array}$ & $\begin{array}{c}1 / 2-\mathrm{Pt} \text {. } \\
.20\end{array}$ & .35 & $\begin{array}{l}Q t . \\
.60\end{array}$ \\
\hline Ameer ................. & .15 & .20 & .35 & .65 \\
\hline Alderman ....... & .15 & .20 & .35 & .65 \\
\hline Gradus or Prosperity & .15 & .20 & .35 & .65 \\
\hline Champion of England...... & .15 & .20 & .35 & .65 \\
\hline 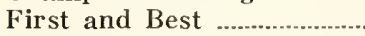 & .15 & .20 & .35 & .60 \\
\hline Tall Telephone & .15 & .20 & .35 & .70 \\
\hline Thomas Laxton & .15 & .20 & .35 & .70 \\
\hline Laxtonian (Extra Fine).... & .15 & .20 & .35 & .75 \\
\hline 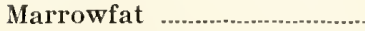 & .15 & .20 & .30 & .55 \\
\hline
\end{tabular}

TURNIP

Amcrican Red Top Globe

Large White Globe

Cow Horn

Purple Top Milan

Seven Top

White Egg

White Flat Dutch …................................

Yellow Aberdeen …............................ .05

Yellow Globe

Ullathorne's Fcy. Mixed...................... .05

Am. P. T. Ruta Baga...................... .05
.10

.10

.25

.25

.50

.50
1.00

1.25

25

1.25

1.75

2.75

3.00

3.50

2.50

2.75

$\begin{array}{lr}.25 & .65 \\ .20 & .50 \\ .25 & .65 \\ .35 & 1.25 \\ .20 & .50 \\ .20 & .45 \\ .25 & .65 \\ .20 & .50 \\ .20 & .50 \\ .20 & .50 \\ .20 & .50 \\ .25 & .60\end{array}$

\section{TESTIMONIALS.}

Gentlemen: Replying to yours of the 6th inst., relative to seed corn purchased from you last spring, beg to advise that our crop is one of the best we have ever grown. Some of our corn will make 100 bushels to acre. We have about 400 acres in all, which will average about 75 bu. to acre. Our land is very fertile.

Yours truly, CHASTAIN BROTHERS.

Gentlemen: The yield from the Paymaster Corn bought of you was exceedingly good, considering the season. I would not wish to plant a better corn for general plantation use. 


\section{FLOWER SEED}

We have taken a great deal of time and care in choosing our list of Flower Seeds and have selected only those varieties which we know to do well in the South. While we are not making any elaborate statements about any of them, we will say that we have hought only the BEST of each. Full directions for growing will be found on every packet.

\begin{tabular}{|c|c|}
\hline geratum. & $\begin{array}{r}\text { Pkt. } \\
.05\end{array}$ \\
\hline weet Alyssum & .05 \\
\hline Antirrhinum (Snap Dragon)........ & .05 \\
\hline STER- & \\
\hline Queen of the Market, Mxd..... & .10 \\
\hline Semples Branching, Mixed...... & .10 \\
\hline 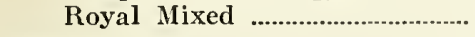 & .10 \\
\hline Bachelor Button ….................................... & .05 \\
\hline Balsam, Ullathorne's Fancy Mx..... & .05 \\
\hline $\begin{array}{c}\text { Balsam Apple, Ullathorne's Fcy. } \\
\text { Mixed }\end{array}$ & .05 \\
\hline Begonia Superflorens, Fcy. Mx..... & .10 \\
\hline Bellis (English Daisy) Fcy. Mx..... & 10 \\
\hline Calendula, Orange King....................... & .15 \\
\hline Canterbury Bells, U. Fcy. Mx....... & .10 \\
\hline 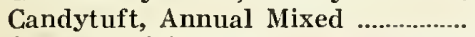 & .05 \\
\hline 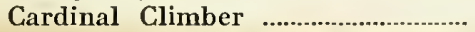 & .10 \\
\hline Carnation, Margaret Mixed ........... & .10 \\
\hline Celosia (Cockscomb) & .05 \\
\hline Centeurea, Emperor William.......... & .05 \\
\hline Cobaea Scandens, Purple (Vine).. & .05 \\
\hline Coleus, Ullathorne's Fcy. Mxd...... & .15 \\
\hline Morning Glory, Fcy. Mixed............ & .05 \\
\hline $\begin{array}{c}\text { Morning Glory, Japanese, Fcy. } \\
\text { Mixed }\end{array}$ & .05 \\
\hline Cosmos, Giant Flowering, Mixed.. & .05 \\
\hline 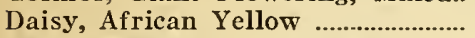 & .10 \\
\hline 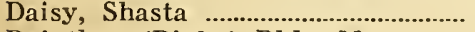 & .10 \\
\hline Dainthus (Pinks) Dble. Mx............. & .10 \\
\hline Fox-Glove Digitalis & .05 \\
\hline Gourds, All Kinds, Mixed .............. & .05 \\
\hline Heliotrope, Mammoth Flower, Mx. & .10 \\
\hline Hibiscus, Mallow Marvels, Mx....... & .10 \\
\hline Hollyhock, Dble. Mxd. Ex. Fine.... & .10 \\
\hline Larkspur, Ullathorne Spec. Mx..... & .10 \\
\hline Lantana Hyrids, Mixed...................... & .10 \\
\hline
\end{tabular}

Oz. $\quad 1 / 4-1 \mathrm{~b} . \quad \mathrm{b}$.

.40

00

1.50

1.50

1.75

1.00

.50

.25

1.00

1.00

.40

.45

60

.35

.30

\section{FIELD SEED}

CLOVER-ALFALFA

Lb. Peck Bu. 100 Lbs.

Kansas Grown, Dry Land.

s 35

$\$ 3.50$

$\$ 12.75$

$\$ 21.00$

Dakota No. 12 (Genuine)

Alsyke

Red Clover, Fancy.

White Dutch

$4.00-15.00-24.50$

$\begin{array}{lll}4.00 & 15.00 & 24.50\end{array}$

$\begin{array}{lll}7.75 & 30.00 & 50.00\end{array}$

Lespedeza (Japan Clover)................. $40 \quad .40 \quad 1.50 \quad 5.00 \quad 19.00$

Melilotus, Hulled, Sweet...........................

\section{GRASSES}

Fancy Red Top (Herds)

Kentucky Blue

Timothy, Fancy Stock

Orchard Grass

Bermuda

Sudan, Fancy Free Johnsongras

Ullathorne's Fancy Lawn Grass

Mixture

\section{MILLET}

Tenn. Golden

10

$\begin{array}{lll}10 & 50 & 100\end{array}$

Lbs. Lbs.

$\begin{array}{lll}3.00 & 14.00 & 27.50\end{array}$

$\begin{array}{lll}6.50 & 32.50 & 60.00\end{array}$

$\begin{array}{rrr}1.50 & 5.50 & 10.00\end{array}$

$\begin{array}{lll}3.00 & 13.00 & 25.00\end{array}$

$\begin{array}{lrr}5.00 & 22.00 & 42.50\end{array}$

$\begin{array}{rrr}1.00 & 3.50 & 5.50\end{array}$

$\begin{array}{lll}5.00 & 22.50 & 42.50\end{array}$

$\begin{array}{lll}.75 & 2.25 & 4.25\end{array}$

$\begin{array}{lll}.60 & 2.00 & 3.75 \\ & 2.00 & 3.75\end{array}$
OATS-Extra Fancy Red R. P.

Weight, 38-lbs. per measured $\mathrm{Br}$.

Bu. 5-Bu. 10-Bu.

1.25

Burt Oats 1.15

Texas Red Rustproof $\quad 1.00$

Fulghum

.75

SORGHUM OR CANE

$10 \quad 50 \quad 100$

Texas Seed Ribbon Cane ............... $\quad 1.00 \quad 3.25 \quad 6.00$

Early Amber ............................................

Early Orange $\quad .60 \quad 1.75 \quad 3.00$

Red Top or Sumac............................ $\quad .60 \quad 1.75 \quad 3.10$

Black Hull White Kafir.................

Feterita …...................................... $\quad .65 \quad 2.00 \quad 3.75$

Milo Maize Dwarf Yellow............... $\quad .65 \quad 2.00 \quad 3.75$

MISCELLANEOUS FIELD SEEDS

Dwarf Essex Rape ........................... 1.75

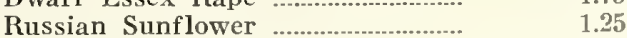

Spring Vetch . 1.25

Broom Corn, Dwarf

Broom Corn, Standard

Buckwheat Silver Hull..
$7.50 \quad 14.00$

$5.50 \quad 10.00$

$5.50 \quad 10.00$

$3.75 \quad 7.00$

$3.50 \quad 6.00$

$3.50 \quad 6.00$

White Wonder

.00

2.25

.25

50 
SOY BEANS

Mammoth Yellow

Biloxi

VELVET BEANS

Early Speckled or 90-Day.

Osceola

PEANU'TS

White Spanish

Long Tenn. Red, Hand Picked.....

Virginia or Jumbo.

N. C. Runners.

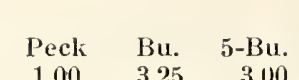

$1.00-3.25 \quad 3.00$

$2.75 \quad 10.00$

$\begin{array}{lll}.75 & 2.50 & 2.25\end{array}$

$\begin{array}{lll}1.00 & 3.25 & 3.00\end{array}$

$10-2 \cdot 2=100$

Lbs. Lbs. Lbs.

$\begin{array}{lll}1.25 & 2.50 & 9.50\end{array}$

$2.00 \quad 3.50 \quad 15.50$

$2.00 \quad 3.75 \quad 16.50$

$1.25 \quad 2.50 \quad 9.50$
SEED POTATOES-Northern Grown

Triumph

Irish Cobbler

Early Rose

Peerless

Early Ohio

Pk. Bu. 21/2-Bu.

$\begin{array}{lll}.85 & 2.75 & 6.75\end{array}$

$\begin{array}{lll}.85 & 2.75 & 6.75\end{array}$

$.75 \quad 2.50 \quad-6.00$

$\begin{array}{lll}.75 & 2.50 & 6.00\end{array}$

$\begin{array}{lll}.75 & 2.50 & 6.00\end{array}$

ONION SETS

1-lb. 4-lbs. 8-lbs. 32-lbs

White Silverskin …........................ $.25 \quad$.65 $1.00 \quad 3.50$

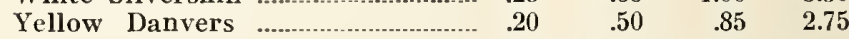

Red Weathersfield …....................... $\quad .20 \quad .50 \quad .85 \quad 3.00$

\section{INSECTICIDES}

Insecticides Cannot Be Sent Through Mail Except Where Noted.

SLUG SHOT, Hammond's-Non-Poisonous; a splendid power for general use. $1 \mathrm{lb} ., 30 \mathrm{c} ; 5 \mathrm{lbs}$, $75 \mathrm{c}$; postpaid. By freight or express, $1 \mathrm{lb} ., 20 \mathrm{c}$; 5 lbs., 60c; 100 lbs., $\$ 9.00$.

ARSENATE OF CALCIUM, DRY POWDERED-It has relatively the quick killing properties of Paris Green, but adheres to leaf for a longer time. 1 lb., 50c; 5 lbs., $\$ 2.00 ; 100$ lbs., $\$ 25.00$.

ARSENATE OF LEAD-Does not burn foliage; kills every insect that eats it and is superior in every way to Paris Green. 1 lb., 50c; $5 \mathrm{lbs}$, $\$ 2.25 ; 10$ lbs., $\$ 4.00$.

PARIS GREEN-1/4 lb., 20c; 1/2 lb., 35c; $1 \mathrm{lb} ., 60 \mathrm{c}$; 5 lbs., $\$ 2.50$.

LIME SULPHUR, DRY POWDERED-The Winter spray when trees are dormant. Controls scale and other pests which attack the bark. $1 \mathrm{lb}$., $35 \mathrm{c} ; 5$ lbs., $\$ 1.50 ; 10$ lbs., $\$ 2.50 ; 25$ lbs., $\$ 4.50$.

BORDO-ARSENATE, DRY POWDERED-An insecticide and fungicide combined. Controls tomato wilt to a certain degree. $1 \mathrm{lb} ., 60 \mathrm{c} ; 5 \mathrm{lbs}$., $\$ 2.50 ; 10$ lbs., $\$ 4.75$.

BORDEAUX MIXTURE, DRY-Controls fungus diseases. 1 lb., 45c; 5 lbs., $\$ 1.75 ; 10$ lbs., $\$ 3.00$.

PYROX-A fungicide and insecticide combined. 1 lb., 40c; 5 lbs., $\$ 1.50 ; 10$ lbs., $\$ 2.50$.

TOBACCO DUST_-Valuable for killing lice on all vegetation. 1 lb., $25 \mathrm{c}$; 5 lbs., $\$ 1.00 ; 10$ lbs., $\$ 1.75$.
SPRAY PUMPS AND SEEDERS.

\section{"SEND FOR BOOKLET ON SPRAYING."}

HAND ATOMIZER-Holds one quart liquid. A cheap, serviceable spray. Tin, 60c; postpaid.

UTILITY SPRAY-Compressed air. Heavy galvanized tank. Holds four gallons. $\$ 6$ each.

THE RITTENHOUSE SEEDER-The popular hand broadcast seeder. Does good work at a cheap price. $\$ 2.00$ each; $\$ 2.20$ each, postpaid.

TIN HORN SEEDER-Simple and easy to operate. Will sow any fine seed. $75 \mathrm{c}$ each, postpaid.

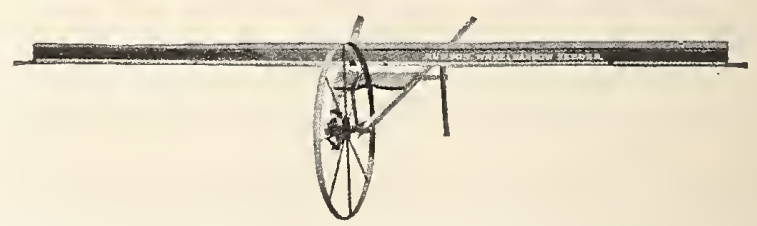

WHEELBARROW SEEDERS-Best for sowing grass or any other light seeds. Does perfect work. $16 \mathrm{ft}$. hopper, $\$ 12.50$ each.

CAHOON BROADCAST SEEDER-Built entirely of steel and will last for years. The best broadcaster made. $\$ 4.75$ each. Postpaid, $\$ 5.00$ each. MOLE TRAPS- $\$ 1.00$ each.

\section{BASKETS.}

Half-bushel round, 1 dozen. $\$ 2.00$

One-bushel round, 1 dozen 2.00

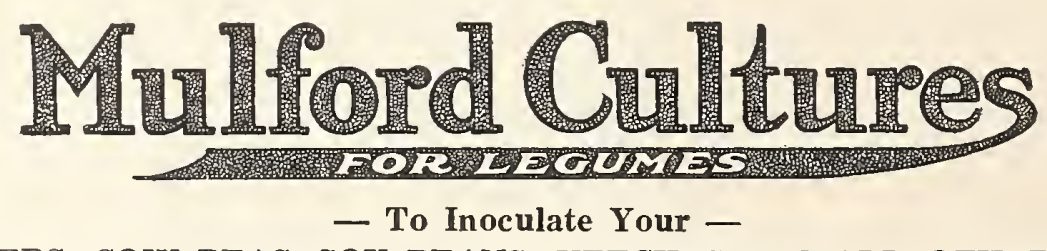

ALFALFA, CLOVERS, COW PEAS, SOY BEANS, VETCHES, and ALL OTHER LEGUME CROPS SMALL COST LARGE RETURNS EASY TO USE NO LABOR EXPENSE

Mulford Cultures contain pure, tested strains of active, vigorous nitrogen-fixing bacteria for inoculating seeds of legumes or soil. Price: 1 acre size, $\$ 1.50 ; 5$-acre size, $\$ 5.00$. 


\section{The JOE L. ULLATHORNE SEED CO. SEED MERCHANTS \\ 26 SOUTH FRONT ST. \\ :: MEMPHIS, TENNESSEE}

Date

192

Ship the following Seeds to

NAME

Postoffice

R. F. D. No.

State

Express or Freight Office

Shall we ship by freight, express or parcel post?

(If by parcel post or charges to be prepaid, add sufficient amount to cover.)
Amount Enclosed

P. O. Order

Express Order

Check

Cash

Stamps

Total

NOTICE-Non Warranty. We give no warranty (express or implied) as to purity, description, quality, pro. ductiveness or any other matter of Seeds, Bulbs or Plants we send out, and we will not be responsible in any way for the crop. If the purchaser does not accept the goods on these terms, they are to be returned at once. NOTE-OUR TERMS ARE NET CASH

\begin{tabular}{c|c|c|c}
\hline Quantity & Kind of Seed Wanted & A & Amount \\
\hline
\end{tabular}

\section{FROM}

\section{RUSH ORDER TO}

\section{JOE L. ULLATHORNE SEED CO. MEMPHIS,}

\section{TENNESSEE}

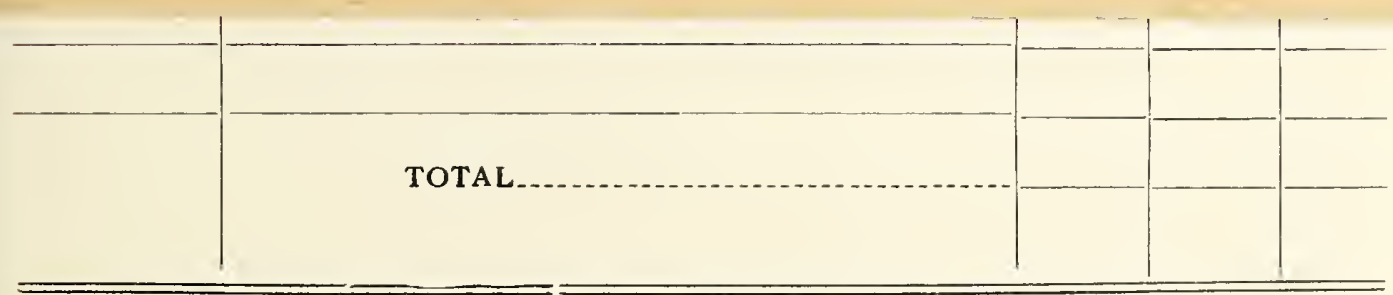

Send us the names of a few friends whom you think would be interested in better seeds. 


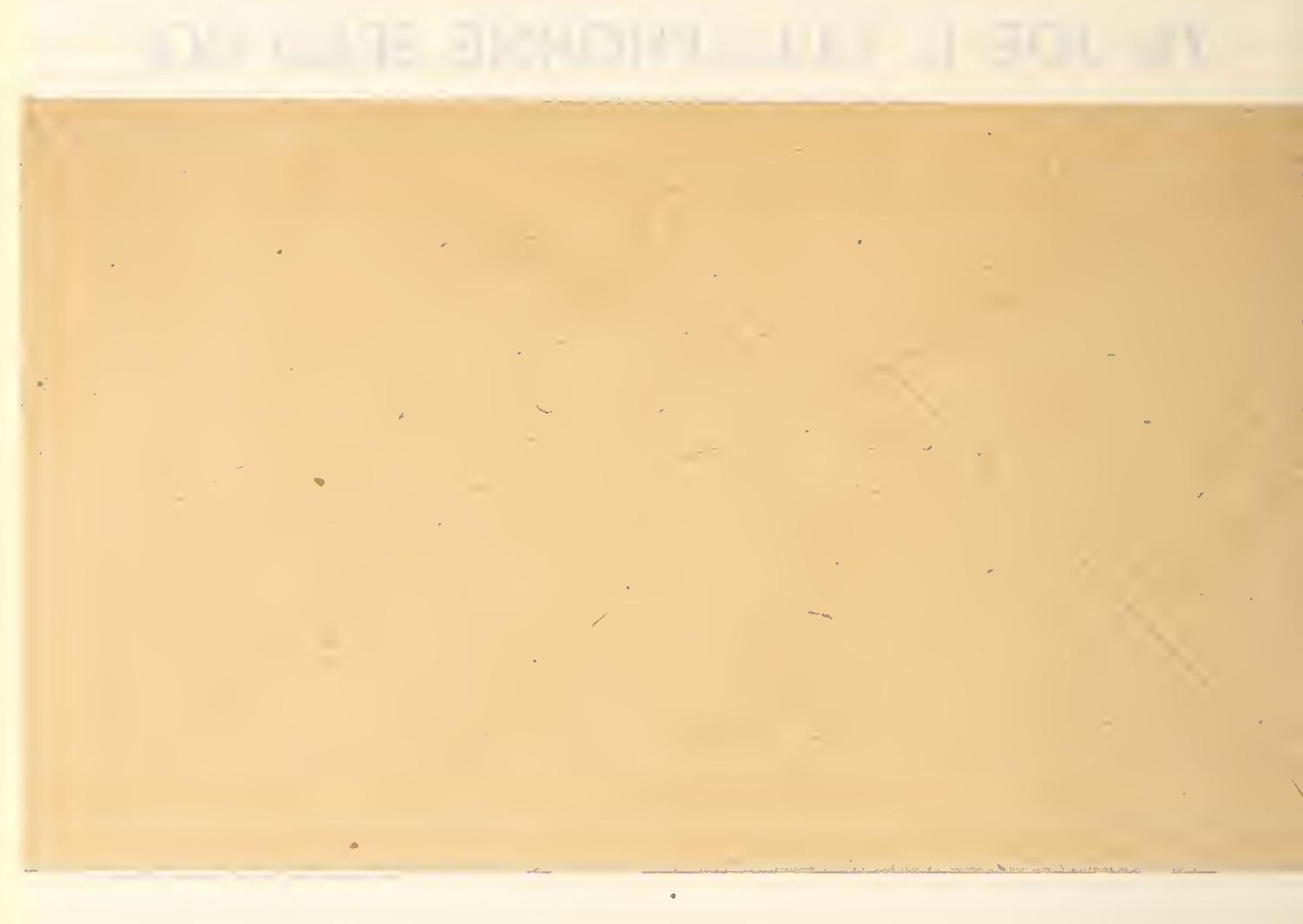


Order through your seed house. Be sure to name the crop it is wanted for.

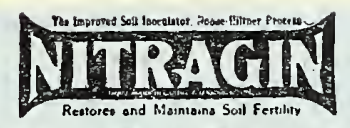

SOIL INOCULATOR
A Gold Medal was awarded "NITRAGIN" at the

St. Louis World's Fair 1904.

\section{A GREAT PRICE REDUCTION}

to farmers growing Alfalfa, Soy Beans, Clovers and other legumes

Bushel Value for Acre Price---NITRAGIN Costs Less

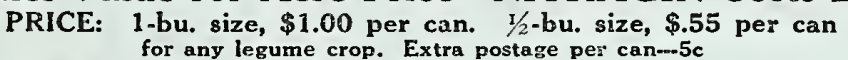

This means NITRAGIN will now cost you

$20 \mathrm{c}$ per acre if you sow $12 \mathrm{lbs}$. seed to the acre

25c per acre if you sow 15 los. seed to the acre

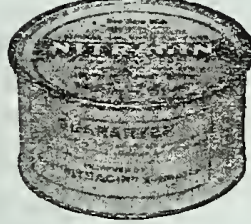

EVERY GARDEN NEEDS NITRAGIN-.-COSTS 15c

A new garden culture for peas, beans and for sweet peas. Is sold in a small size, just right for the average garden. It costs only $15 \mathrm{c}$ with your garden seed order; or 17e if mailed separate.

When ordering garden state if you want it for beans, peas or sweet peas. They are in different packages; each at 15c or $17 \mathrm{c}$ if it is a separate order. If you order Nitragin for field crops always state what crop you want it for-there are different
kinds. All cost the same.

Distributed By

THE JOE L. ULLATHORNE SEED CO.,

26 S. Front St., MEMPHIS, TENNESSEE 


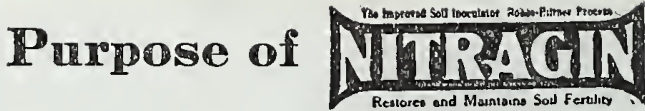

Many growers say "Oh we can get a catch in these parts without inoculating." This may be true, but what kind of a catch?

The modern farmer says "I inoculate because I want a better catcb. I want plenty of tbose little nodules or lumps on every root. The more the better."

"Nodules are plant food (nitrogen). They mean a well-fed legume plant."

"Well nourished legume plants mean less WINTER KILLING. They can put up a good fight against pests because they are healtby and strong. Tbey have a deeper root system."

"More nodules mean a more even stand instead of bare spots all tbrough the field, therefore I get a better yield and that is what I am after."

"The more nodules I plow under, the more plant food for tbe srop in rotation. I do not rob my soil of nitrogen, I add to it."

"Is it worth while? Your state agricultural department says

I know it is from experience A well inoculated field mean $\checkmark$ from 150 to 200 pounds of nitrate (plant food) placed back into my soil. Compare the cost of 200 pounds nitrogen fertilizer with the I cost of NITRAGIN and this year NITRAGIN is only costing me around 25c per acre."

过

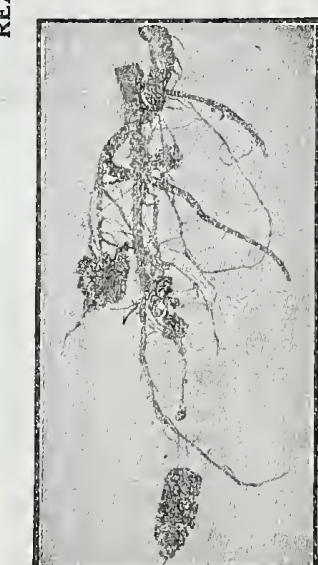

(No, 11-R-22)
NITRAGIN is shipped in ventilated tin boxes. The package never breaks, never freczes and is simple to use. Germs must have air and moisiure. The contents look like a deep rich soil. It is clean and wholesome. It is practical as soil is the natural home for nitrogen gathering germs.

NITRAGIN is the first of its kind, the original. Consult any library. Was registered in the United States, Dec. 6th, 1898, No. 32212.

Be sure and state the name of the legume crop you are going to inoculate.

Order Thru Your Seed House

The well known trade mark "NITRAGIN" and name of the manufacturer "The Nitragin Company, Ine. Milwaukee, Wis." is your guarantee of quality in the product you buy.

There is crly one Nitragin-it is protecied by the trade mark. 


\section{ULLATHORNE'S INOCULATING BACTERIA}

\section{THE GUARANTEED LEGUME INOCULATOR GROWN DIRECT FROM NODULES-HIGHEST POSSIBLE VIRILITY.}

Increases the Yield-Enriches the Soil-Hastens Maturity-Improves the Feeding Value-Saves Fertilizer Bills-Easy to Apply; Full Directions in Every Package.

Bulletin No. 53, South Carolina Experiment Station says: "Inoculation is not a cure-all, but its proper use will send the farmer farther forward in three years than it has been possible for him to go without it in a generation."

Ullathorne's Inoculating Bacteria are not cheap cultures. They may be cheaper in price than some, but in price only. The price is still consistent with high quality. They cannot be made better, even if ten times the prices were offered. Every package is fully guaranteed. Prepared for Alfalfa, Red Clover, Cow Peas, Soy Beans, etc. 1-acre size, $75 \mathrm{c} ; 2$-acre size, $\$ 1.40 ; 6$-acre size, $\$ 3.00$, postage paid.
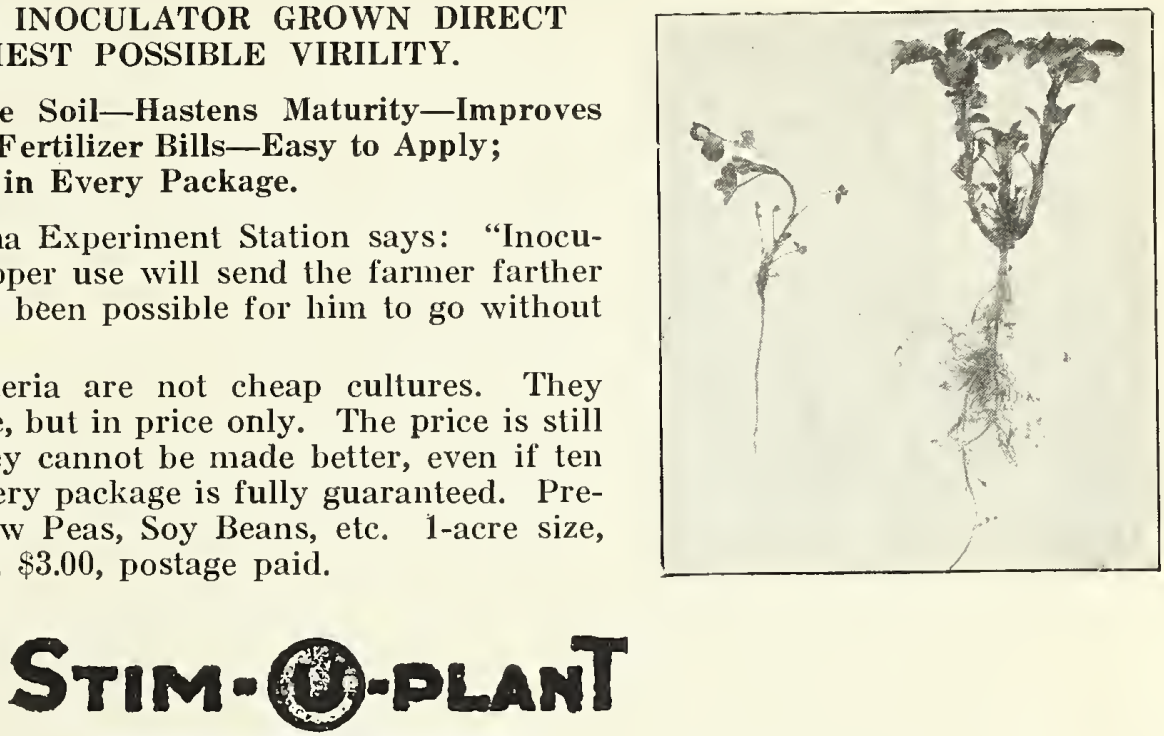

PLANT STIMULANT TABLET

\section{AN ALL-THE-YEAR FERTILIZER FOR GARDEN AND HOUSE PLANTS}

Growers of fine flowers, shrubs and vegetables for the best markets and for exhibition, fertilize and stimulate them frequently; a little at a time. An excellent fertilizer for this purpose is Stim-U-PlanT, an odorless, highly concentrated plant-food, in tablet form, with guaranteed chemical analysis of 11 per cent nitrogen, 12 per cent phosphoric acid, 15 per cent potash. The proportions are accurate, there is no unnecessary filler, and in this form you are able to apply plant-food exactly when and where and as needed.

\section{MAKE YOUR GARDEN A WONDER GARDEN}

These tablets increase production, heighten color and improve quality. Many professional and amateur growers use them extensively all the year round-from early spring until late fall outdoors, during the winter for pot plants, hot-house benches, etc. They are equally good for evergreens and other trees as for a small fern, petunia or other potted plant.

Stim-U-PlanT Tablets can be used in tablet form, or dissolved in water at the rate of one tablet to the quart. Complete directions with every package.

Order Stim-U-Plan'T Tablets with your seed and plant order. Price, 10 tablets for 15c; 30 for 25c; 100 for $75 \mathrm{c} ; 1,000$ for $\$ 3.50$.

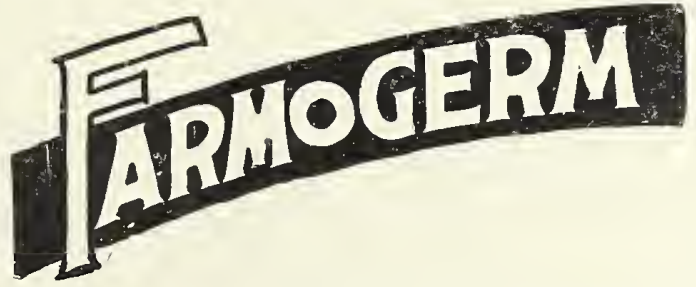

\section{FARMOGERM-A SEED INOCULANT THAT INCREASES CROP PRODUCTION.}

Seed of all legumes-beans, peas, clover, alfalfa, and related crops-will produce far better if inoculated with Farmogerm. In addition to the increased crops, these legumes leave in the soil a heavy deposit of nitrogen which benefits all succeeding crops. Gardeners and farmers who have used Farmogerm would not be without it.

\section{FARMOGERM PRICES REDUCED.}

New scientific methods of manufacture have given lower prices. You cannot now afford to do without Farmogerm.

A special composite culture is prepared for peas, beans, and sweet peas, $1 / 4$-acre size only. You'll get more peas and beans, and larger sweet peas by using this. Ask for No. 5, price 50c.

Farmogerm prices are: 1 -acre size, $\$ 1$; 3 -acre size, $\$ 2.50 ; 12$-acre size, $\$ 9$. Full directions accompany each bottle. 


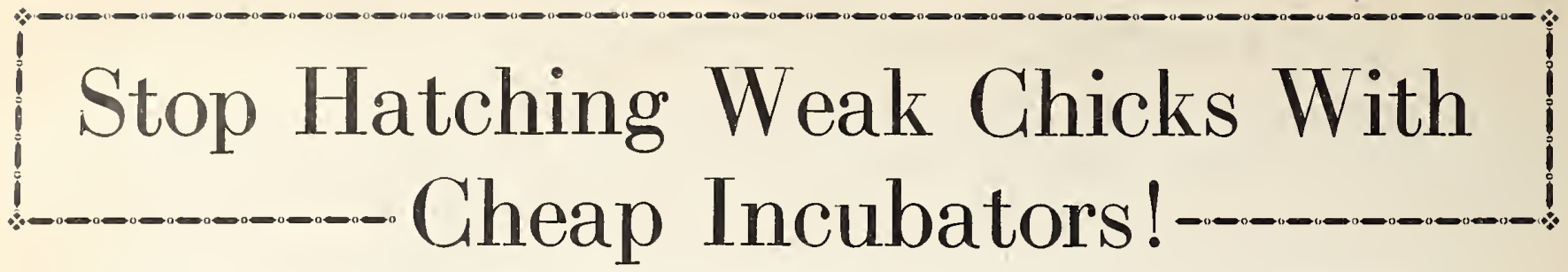

A Queen costs but little more, and the extra chicks that live and grow soon pay the difference.

Remember, it is not how many chicks you HATCH that counts, but how many you RAISE. Chicks that hatch out weak and wobbly, and live but a few days, mean nothing to you but trouble and loss. They make one sick of the poultry business.

Most of the chicks you lose in the first few weeks die because they did not have, when hatched, enough strength or vitality for a good start. Queen Incubators are famous the country over for big hatches of strong, healthy chicks that live and grow.

Proper Insulation-The Queen is doubly insulated. First, we use double walls of California Redwood, forming a dead air space. Second, corrugated strawboard is used between the wooden walls. Proper insulation adds considerable expense to the manufacturing cost. However, it is an absolute requirement of a good Incubator.

Queen Hot Water Heating-The Queen System of hot water heating prevents the drying-out tendencies found in hot air incubators and provides a soft, uniform heat over every part of the egg chamber-a heat that is most natural for the hatching eggs. The circulation of water through the radiator prevents any moisture being added or taken away from the eggs. When it becomes necessary to remove the lamp, the hot water circulating through the radiator maintains an even heat within the egg chamber without the slightest variation.

Built of California Redwood-The Queen is the only Incubator that carries out the double redwood wall construction all around, and provides a double wall front, in the way of two separate doors. The outer door is a solid panel of Redwood that is hinged entirely independent of the inner door and is fastened with a sash lock that draws it tight, thus making the loss of heat impossible.

The imer door is also of redwood construction, containing a panel of glass the full length and height of the egg chamber.

Redwood does not absorb the odor from the hatching eggs. Cheaper woods, and pasteboard lining in iron and tin machines, retain the odors, to weaken and kill the hatching chick.

Queen Incubators are not cheap, but they are cheap in the long run. They will be turning out good hatches years after the cheap machines have been junked.

\section{QUEEN STYLE K INCUBATORS}

No. $20-70$ egg size, $\$ 16.50$; No. $21-135$ egg size, $\$ 27.50$; No. $22-220$ egg size, $\$ 36.75$.

WRITE FOR CATALOGUE AND COMPLETE PRICE LIST FOR INCUBATORS AND BROODERS.

\section{NITRAGIN SOIL INOCULATOR}

\section{A GREAT PRICE REDUCTION TO FARMERS GROWING ALFALFA, SOY BEANS, CLOVER AND OTHER LEGUMES}

Bushel Value for Acre Price-NITRAGIN Costs Less. PRICE: 1 -bu. size $\$ 1.00$ per can; $1 / 2$-bu. size, $55 \mathrm{c}$ per can; for any legume crop. Extra postage, per can, 5c.

This means NITRAGIN will now cost you $20 \mathrm{c}$ per acre if you sow $12 \mathrm{lbs}$. seed to the acre; $25 \mathrm{c}$ per acre if you sow $15 \mathrm{lbs}$. seed to the acre; $331-3 \mathrm{c}$ per acre if you sow $20 \mathrm{lbs}$. seed to the acre.

\section{EVERY GARDEN NEEDS NITRAGIN-COSTS 15c}

A new garden culture for peas, beans and for sweet peas. Is sold in a small size, just right for the average garden. It costs only 15c with your garden seed order; or 17c if mailed separate.

When ordering garden state if you want it for beans, peas or sweet peas. They are different packages; each at $15 \mathrm{c}$ or $17 \mathrm{c}$ if it is a separate order.

If you order Nitragin for field crops always state what crop you want it for-there are different kinds. All cost the same. 